\title{
RUDI (RUMAH DISKUSI) SEBAGAI UPAYA INOVATIF DALAM E-LEARNING
}

\author{
Nabilatul Inayah \\ Universitas Muhammadiyah Surakarta \\ J1. A. Yani, Mendungan, Pabelan, Kec. Kartasura, Kabupaten Sukoharjo, Jawa Tengah 57162 \\ Email: A310160145@student.ums.ac.id \\ Ihdy Khafida Zahra \\ Universitas Muhammadiyah Surakarta \\ J1. A. Yani, Mendungan, Pabelan, Kec. Kartasura, Kabupaten Sukoharjo, Jawa Tengah 57162 \\ Email: A310160144@student.ums.ac.id \\ Tafiv Awalia Noviati \\ Universitas Muhammadiyah Surakarta \\ J1. A. Yani, Mendungan, Pabelan, Kec. Kartasura, Kabupaten Sukoharjo, Jawa Tengah 57162 \\ Email: A310160143@student.ums.ac.id
}

\begin{abstract}
This research have two destination. First, develop Rudi (Discussion House) as that application help the discussion between students and teacher when at home or in school. Second, revealing effectiveness Rudi as an effort innovative e-learning. Which method used in this research is a model ADDIE (Analysis-Design-Develop-Implement-Evaluate), which is one of design model learning which is shows the stages that design simple and easy to learn. The results of this research show that Rudi (House Discussion) can improve relations inter social students and teachers. Besides that, in learning e-based learning Rudi (House Discussion) is able be an alternative in the process learn how to teach.
\end{abstract}

Keywords:

RuDi (Discussion House); E-learning; application; ADDIE

\begin{abstract}
Abstrak
Penelitian ini memiliki dua tujuan. Pertama, mengembangkan Rudi (Rumah Diskusi) sebagai aplikasi yang membantu diskusi antar siswa dan guru ketika di rumah maupun di sekolah. Kedua, mengungkap keefektifan Rudi sebagai upaya inovatif $e$-learning. Metode yang digunakan dalam penelitian ini adalah model ADDIE (Analysis-Design-Develop-Implement-Evaluate), yang merupakan salah satu model desain pembelajaran yang memperlihatkan tahapan-tahapan desain yang sederhana dan mudah dipelajari. Hasil dari penelitian ini menunjukan bahwa Rudi (Rumah Diskusi) dapat meningkatkan hubungan sosial antar siswa dan guru. Selain itu, dalam pembelajaran berbasis e-learning Rudi (Rumah Diskusi) mampu menjadi alternatif dalam proses belajar mengajar.
\end{abstract}

Kata Kunci:

RuDi (Rumah Diskusi); E-learning; aplikasi; ADDIE

\section{A. PENDahuluan}

Selama 74 tahun Indonesia merdeka telah terhitung sepuluh kali mengalami perubahan kurikulum. Diawali pada tahun 1947 atau disebut dengan kurikulum Rentjana. Pelajaran. 1947 akan tetapi baru diterapkan di sekolah-sekolah pada tahun 1950. Melihat kondisi Indonesia yang baru saja merdeka kurikulum tidak mengajarkan berupa pendidikan pikiran akan tetapi hanya mengajarkan pendidikan sifat agar memiliki kesadaran bermasyarakat dan bernegara. Dua tahun kemudian kurikulum tersebut. Diperbarui menjadi kurikulum Rentjana Pelajaran. Terurai 1952 yang sudah mengajarkan pendidikan Indonesia. Pada kurikulum ini sudah menghubungkan
Pembelajaran ke kehidupan sehari-hari dan sudah membuat silabus yang menunjukan seorang guru mengajar suatu pelajaran. Dua tahun berikutnya mengalami perubahan kurikulum lagi yaitu disebut dengan kurikulum Rentjana Pendidikan 1964. Kurikulum ini terkenal dengan program Pancawardhana, yaitu pengembangan moral, kecerdasan, emosional atau artistik, keprigelan atau keterampilan dan jasmani, selain itu pemerintah menginginkan pada agar siswa mendapatkan pengetahuan akademik untuk pembekalan pada jenjang SD. Begitu juga dengan kurikulum 1968 yang tidak jauh berbeda dengan kurikulum sebelumnya yaitu kurikulum Rentjana Pendidikan 1964 yang merupakan wujud realisasi 
pembukaan UUD 1945 yang materi pelajarannya memiliki sifat teoritis. Pada kurikulum ini hal yang harus dicapai oleh peserta didik adalah meningkatkan kecerdasan, kemampuan serta memiliki badan yang sehat sekaligus kuat. Beberapa tahun kemudian tepatnya pada tahun 1975 kurikulum kembali diubah yang lahirnya kurikulum tersebut merupakan pengaruh dari konsep di bidang MBO (management by objective), yang semua komponennya dijabarkan dalam prosedur pengembangan sistem instruksional (PPSI) yang lebih dikenal dengan rencana pelajaran satuan bahasan, kemudian kurikulum ini disempurnakan lagi pada tahun 1984. Selain nama tersebut, kurikulum ini juga biasa disebut dengan Kurikulum 1975 disempurnakan. Dalam kurikulum ini peserta didik dijadikan sebagai subjek dalam kegiatan belajar mengajar, yang bisa disebut juga dengan Cara Belajar Siswa Aktif (CBSA) yang kegiatannya mulai dari mengamati sampai pada tahap membuat laporan.

Sepuluh tahun kemudian tepatnya pada tahun 1994 kurikulum kembali mendapat pembaruan, namun kurikulum yang telah diperbarui justru mendapat kritikan dari masyarakat karena terlalu banyak yang dibebankan kepada peserta didik. Akhirnya pada tahun 2004 dilakukan perubahan lagi yang sering dikenal dengan Kurikulum Berbasis Kompetensi (KBK). Kurikulum ini merupakan kompetensi yang memiliki tiga unsur pokok yaitu memilih kompetensi yang sesuai, menspesifikan indikator sebagai evaluasi dalam keberhasilan kompetensi yang dicapai dan pengembangan pembelajaran.

Kurikulum Berbasis Kompetensi ini menekankan pada pencapaian peserta didik secara klasikal, keberagaman dan orientasi hasil belajar. Proses belajar mengajar menggunakan kurikulum ini tidak hanya bersumber pada guru, melainkan sumber-sumber belajar edukatif lainnya. Baru dua tahun kurikulum berbasis kompetensi berjalan, pemerintah melakukan perubahan kembali pada tahun 2006 yang biasa disebut Kurikulum Tingkat Satuan Pendidikan (KTSP). Kurikulum Tingkat Satuan Pendidikan mirip dengan Kurikulum Berbasis Kompetensi. Perbedaannya, pada Kurikulum Berbasis Kompetensi kewenangan penyusunan kurikulum mengacu pada penyerahan kekuasaan sistem pendidikan di Indonesia. Sedangkan Kurikulum 2006, terpacu pada pemerintah pusat yang langsung menetapkan standar kompetensi dan kompetensi dasar sebagai target pencapaian belajar peserta didik. Disini guru diharapkan dapat mengembangkan silabus dan penilaian dari setiap mata pelajaran dengan mengacu pada kondisi sekolah.

Pada tahun 2013 terjadi perubahan yang cukup besar di dalam dunia pendidikan. Kurikulum kembali berganti menjadi kurikulum 2013 yang merupakan pengembangan dari kurikulum sebelumnya, yang salah satunya adalah peserta didik diharuskan dapat berbicara atau diskusi mengungkapkan pendapatan di hadapan banyak orang, baik secara langsung (lisan) maupun tidak langsung (tulisan). Hal ini sejalan seperti yang dikemukakan oleh Nasucha dkk (2015) bahwa pembelajaran yang berpusat pada peserta didik dapat menjadi wadah bagi peserta didik dalam menyampaikan ide, makna atau gagasan yang mereka miliki. Sehingga pembelajaran ini siswa saling berdiskusi untuk memecahkan permasalahan yang ada. Ditambah perkembangan industri 4.0 mengharuskan setiap peserta didik untuk mengenal teknologi yang semakin pesat. Departemen pendidikan nasional juga gencar mendorong sekolah untuk mengembangkan e-learning untuk memberikan layanan kepada peserta didik dengan lebih mudah lagi. Melihat tatanan kehidupan yang semakin mengalami perubahan, mengembangkan $e$ learning menjadi salah satu hal yang harus dilakukan yang secara langsung maupun tidak langsung mengubah pandangan dalam dunia pendidikan di era globalisasi saat ini yang semakin berkembang. Menilik dari hal tersebut, setidaknya terdapat dua tantangan yang mau tidak mau harus dilalui dalam dunia pendidikan. Tantangan tersebut adalah berubahnya paradigma terhadap dunia belajar itu sendiri dan berbagai kemudahan yang telah disuguhkan oleh teknologi komunikasi dan informasi yang semakin maju dan begitu pesat dalam pembelajaran. Banyak perangkat yang sudah berkembang yang dimanfaatkan dalam dunia pendidikan atau pembelajaran. Seperti e-mail, schoology, telegram, brainly, quora dan lain-lain. Oleh karenanya melihat kondisi tersebut tidak dipungkiri kebutuhan akan multimedia interaktif semakin dirasakan. Maka Pada penelitian ini. menggabungkan tuntutan Kurikulum Berbasis Kompetensi yaitu peserta dapat berbicara atau 
berdiskusi secara langsung maupun tidak langsung dan perkembangan teknologi informasi dengan menciptakan sebuah aplikasi yang bernama RuDi yang digunakan untuk peserta didik berdiskusi secara online mengenai pembelajaran dengan tetap pantauan guru. Aplikasi ini sendiri terinspirasi dari blended learning yang memiliki keefektifan dalam pembelajaran karena blended learning tidak memandang jarak. Contohnya dalam mengapresiasi puisi yang diunggah ke media sosial dapat ditinggalkan berupa tanggapan dari apa yang telah ia lihat ataupun dari orang lain. (Huda, 2018)

Dengan aplikasi yang penulis rancang ini, diharapkan peserta didik dapat mengembangkan kreativitasnya sekaligus dapat berdiskusi secara tidak langsung. Hal ini melatih dua kemampuan sekaligus, yaitu peserta didik dengan begitu akan terbiasa menggunakan teknologi yang semakin berkembang sehingga, peserta didik dapat menyesuaikan dirinya di zaman yang semakin maju. Selain peserta didik diharapkan dapat menyatakan pendapatnya secara langsung atau lisan. Peserta didik juga dituntut memberikan komentar atau dapat berdiskusi secara tulisan dengan baik, yaitu menggunakan bahasa yang baik dan tetap mengikuti norma-norma yang berlaku dalam masyarakat sehingga bisa berguna di kehidupan bermasyarakat peserta didik.

Pada tahun 2013, Winarno dan Johan Setiawan melakukan penelitian dengan judul Penerapan Sistem E-Learning pada Komunitas Pendidikan Sekolah Rumah (Homeschooling) dengan hasil Moodle sukses dilaksanakan sebagai sistem e-learning dengan sifat open source tidak memerlukan biaya, selain itu memiliki akses yang lengkap. Sedangkan pada tahun 2012 Mohammad Yazdi menulis tentang E-learning sebagai Media Pembelajaran Interaktif Berbasis Teknologi Informasi yang menghasilkan Prototipe bahan ajar e-learning yang telah disempurnakan sesuai dengan existing system terpecah menjadi dua bagian yaitu informasi atau konten guru seperti membuat soal, membuat pengumuman, mengunggah bahan ajar sampai melakukan evaluasi pembelajaran dan peserta didik seperti melihat pengumuman akademik, sampai mengunduh bahan ajar dan berbagai macam tugas yang telah diberikan oleh guru.

E-learning memiliki banyak pengertian. Seperti Hartley (2011) mengemukakan e-learning adalah sebuah tindakan yang dilakukan oleh seorang pengajar untuk memberikan materi ajar kepada peserta didik dengan bantuan internet. Tidak jauh berbeda seperti yang dikatakan oleh ahli sebelumnya, Glossary (2001) menyatakan elearning adalah belajar menggunakan media elektronik. Berdasarkan pengertian yang telah dijabarkan di atas, dua hal komponen yang berkaitan dengan e-learning adalah jaringan internet dan media elektronik yang saling berkaitan. Selain dua komponen tersebut dalam elearning juga memerlukan konten yaitu berupa bahan ajar yang bentuknya teks atau multimedia interaktif.

Setelah komponen tersebut telah tersedia, berikutnya adalah merancang e-learning yang terdiri dari empat tahapan. Tahap pertama adalah perencanaan e-learning. Hal yang paling awal dilakukan dengan melihat keadaan dan hal-hal apa saja yang dibutuhkan baik di sekolah maupun peserta didik. Selanjutnya langkah yang kedua yaitu mempersiapkan Infrastruktur e-learning seperti web server untuk mengganti bahan ajar atau materi dan koneksi internet yang cepat. Selain itu persiapan infrastruktur juga dapat berupa pelatihan untuk guru dan peserta didik. Berikutnya langkah ketiga yaitu mempersiapkan konten dan konteks e-learning. Konten sendiri dapat berupa bahan pembelajaran yang nantinya harus diberikan kepada peserta didik lewat media e-learning yang telah dipersiapkan. Materi ajar yang disediakan biasanya terdapat dua jenis yaitu text based content yang terdiri dari dokumen yang akan disampaikan bisa berupa suara dan video. Sangat perlu untuk membuat para siswa menjadi tertarik dalam melakukan pembelajaran elearning, oleh karena itu diperlukan strategi yaitu dengan menambahkan ilustrasi, animasi atau gambar yang mendukung pembelajaran agar lebih menarik, untuk itu diperlukan seorang ahli dalam bidang design. Tahap terakhir yang perlu dilalui yaitu persiapan berupa sistem e-learning yang dapat menunjang metode maupun strategi pembelajaran yang paten dibutuhkan sebelum peluncuran media yang sedang dibuat.

Penelitian ini merupakan penelitian jenis R\&D. Research and development merupakan sebuah jenis penelitian mengembangkan sebuah produk dan nantinya produk tersebut diuji keefektifannya setelah selesai diciptakan. Sedangkan metode yang digunakan dalam 
penelitian ini adalah ADDIE (Analysis-DesignDevelop-Implement-Evaluate). Metode ini terdiri dari lima tahap pengembangan yaitu yang pertama adalah Analysis, yaitu sebuah tahap yang harus dilakukan pertama kali oleh seorang peneliti dalam hal mengembangkan proses belajar mengajar. yang harus dilakukan oleh seorang pengembang pembelajaran. Menurut Kaye Shelton dan George Saltsman (2007) terdapat tiga elemen yang harus dianalisis oleh seorang pegembang pembelajaran yaitu media yang digunakan untuk menyalurkan materi ajar, pembelajaran itu sendiri, karakteristik siswa yang akan menggunakan alat tersebut serta hal yang paling penting adalah tujuan atau kompetensi yang akan diraih peserta didik setelah menggunakannya. Tahap yang kedua adalah desain, yang dilakukan berdasarkan dari hasil analisis yang sudah dilakukan. Seperti membuat silabus dan seperangkat lampirannya seperti materi ajar strategi pembelajaran dan lain-lain. Langkah berikutnya yang ketiga adalah development. Dalam data ini merupakan tahap mewujudkan apa yang sudah didesain seperti membuat gambar, animasi, video, objek-objek yang digunakan dalam pembelajaran dan dokumen yang menunjang lainnya. Langkah selanjutnya adalah implementation yaitu tahap dimana semuanya sudah siap dipakai oleh siswa. Kemudian tahap atau langkah yang terakhir adalah evaluation atau berupa penilaian atau evaluasi dalam bentuk formatif (selama proses berlangsung) maupun sumatif (ketika proses telah berakhir).

\section{B. HASIL DAN PEMBAHASAN PENELITIAN}

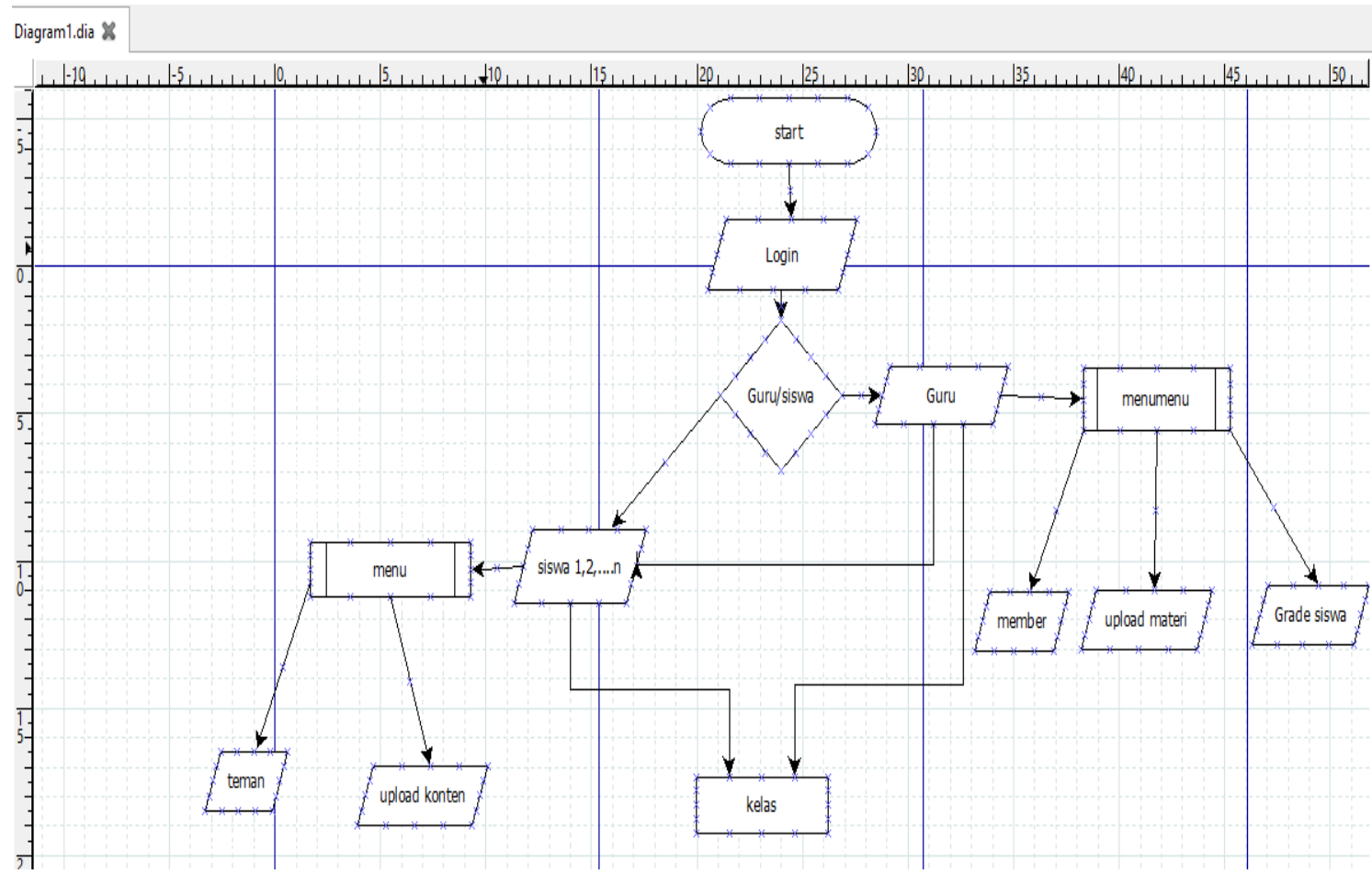

Gambar 1. Flowchart Aplikasi RUDI

Dalam aplikasi ini memiliki tiga fitur yang nantinya bisa digunakan oleh user (guru dan siswa), yaitu diskusi, materi dan komunikasi. Pada fitur diskusi siswa dapat saling memberikan komentar di konten yang telah diupload oleh salah satu siswa, semua siswa dapat mengunjungi semua akun. antar temannya, sedangkan pada.fitur materi guru maupun siswa dapat mengunggah sebuah materi atau konten yang akan didiskusikan. Fitur terakhir yaitu komunikasi baik guru dengan siswa maupun antar siswa bisa saling bertukar informasi pribadi. Setiap user (guru dan siswa) memiliki hak akses yang berbeda. Guru memiliki hak akses mengunggah materi, melihat. aktivitas siswa, melihat room siswa dan dapat memberikan arahan maupun 
komentar saat berdiskusi, sedangkan untuk siswa memiliki hak akses yaitu melihat materi, berdiskusi, kelompok (kelas) berdiskusi pribadi (memberikan komentar di konten siswa lainnya)

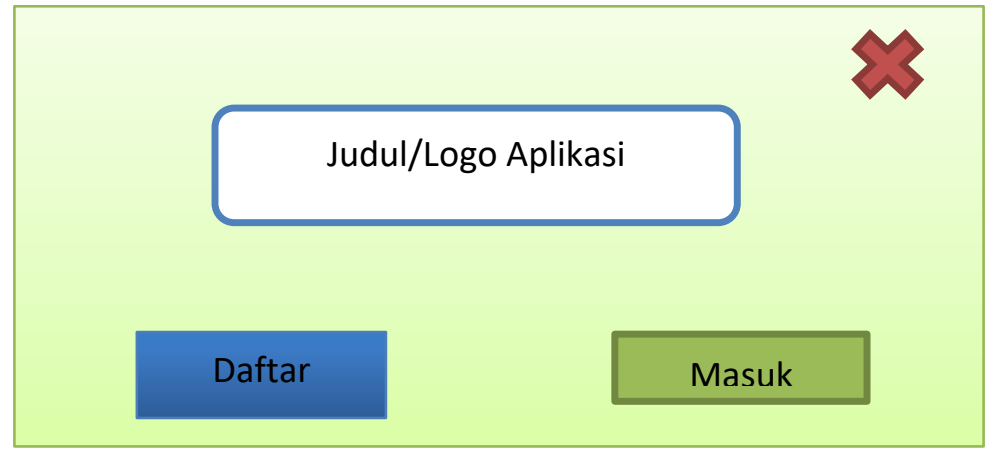

Gambar 2. Tampilan Awal

Pada tampilan. awal ini, diharapkan setiap siswa memiliki akun agar memiliki akses di aplikasi ini. Maka sebelumnya, siswa memilih tombol daftar dan mengisi beberapa identitas diri. Jika siswa sudah melakukan pendaftaran, namun.
Rumah Diskusi belum dilakukan, siswa bisa meninggalkan laman tersebut dan bisa mengunjunginya kembali ketika diskusi akan dimulai. Saat diskusi dimulai maka pada tampilan awal siswa memilih tombol masuk.

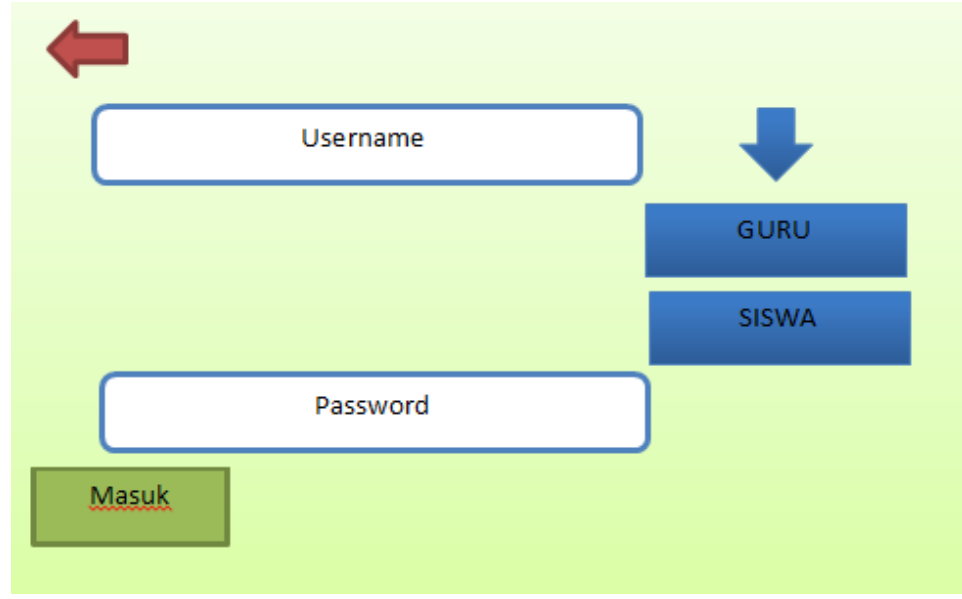

Gambar 3. Tampilan Log in

Setelah memilih tombol masuk akan muncul seperti tampilan tersebut. Untuk siswa memilih item SISWA kemudian siswa mengisi username dan password yang sudah diisi saat mendaftar. Setelah itu pilih item masuk untuk memasuki Rumah Diskusi.

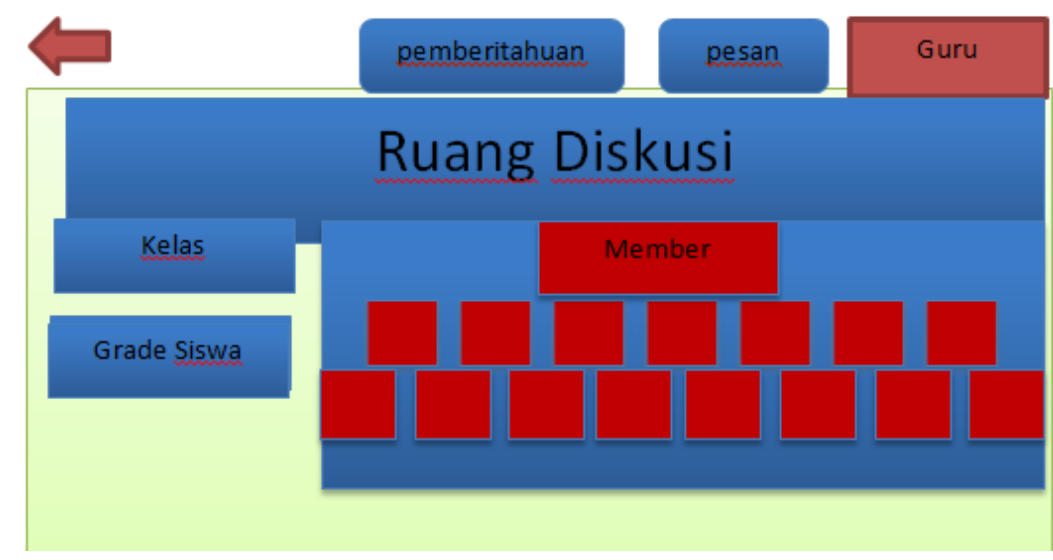

Gambar 4. Tampilan Menu Guru 
Gambar yang disajikan di atas adalah tampilan dari Rumah Diskusi oleh akun guru. Pada akun guru terdapat menu pemberitahuan, pada menu pemberitahuan berisi tentang pengumuman dari siswa apabila telah mengunggah sebuah konten, berdiskusi dan memberikan komentar antar siswa. Pada menu pesan merupakan ruang bagi siswa bertanya ada guru. Pada menu member berisi anggota siswa yang berada dalam satu rumah diskusi atau satu kelas. Update materi merupakan menu untuk mengupload materi, sedangkan pada menu grade siswa menampilkan peringkat siswa, melihat siswa yang paling aktif dan yang tidak aktif. Pada Ruang Diskusi merupakan aktivitas siswa dalam melakukan diskusi.

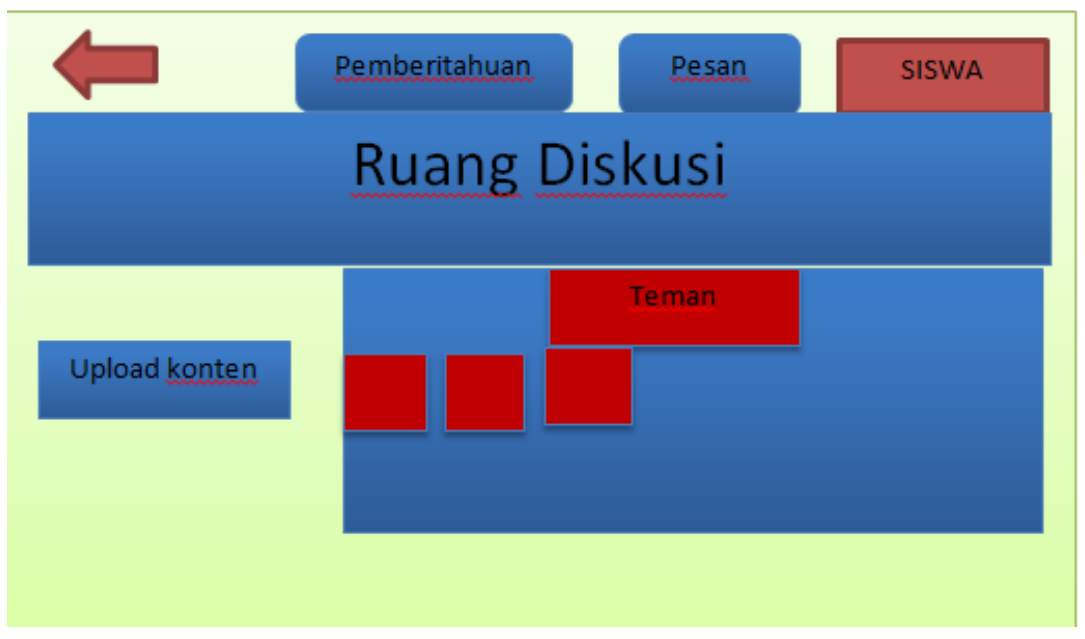

Gambar 5. Tampilan Menu Siswa

Pada tampilan gambar tersebut merupakan gambaran tampilan untuk siswa. Pada menu pemberitahuan berisi tentang pemberitahuan tugas dari guru dan pemberitahuan dari teman apabila memberikan komentar terhadap konten yang telah diunggah. Pada menu. pesan digunakan siswa untuk berinteraksi dengan siswa lainnya dan jika ada pertanyaan yang ingin ditanyakan kepada guru. Pada menu teman berisi anggota Rumah Diskusi yang berada dalam satu kelas. Upload konten digunakan siswa untuk mengunggah materi yang akan digunakan diskusi. Ruang diskusi digunakan sebagai aktivitas siswa untuk berdiskusi atau bertukar materi yang sudah dipersiapkan.

Sebelum guru memulai menggunakan aplikasi Rudi (Rumah Diskusi) adapun langkahlangkah yang perlu dipersiapkan oleh guru seperti:

1. Menganalisis (karakter dan kemampuan) peserta didik;

2. Menentukan materi ajar (KD 3.17 teks puisi);

3. Menentukan tujuan yang akan dicapai (kompetensi)

4. Menentukan media yang akan digunakan.
Guru harus memastikan siswa memiliki akun masing-masing dengan posisi online. Kemudian guru menyampaikan materi yang akan diajarkan. Misal membuat teks puisi yang bertema lingkungan, maka siswa harus mempelajari materi mengenai unsur-unsur pembangun puisi terlebih dahulu. Guru memberikan jangka waktu tertentu untuk siswa membuat puisi. Setelah itu siswa sudah bisa memasukan akun untuk upload teks puisi tersebut. Barulah, ruang diskusi dimulai. Disini siswa bisa saling meninggalkan komentar mengenai puisi yang dibuat. oleh antar siswa. Tak hanya itu, pada RuDi (Rumah Diskusi ) ini juga dapat digunakan siswa untuk berdiskusi secara berkelompok tanpa lepas dari pantauan guru hasil dari Rumah Diskusi. ini pun selain dari tugas yang telah dikerjakan juga dapat menunjukkan keaktifan siswa. Sehingga guru dapat membuat grade dalam satu Rumah Diskusi atau satu kelas.

Rumah diskusi ini menjadi inovatif baru dalam pembelajaran e-learning adalah sebuah proses belajar mengajar yang dilakukan oleh pengajar untuk memberikan materi ajar kepada peserta didik dengan bantuan internet. Selain itu pada penelitian Wayan Lasmawan. (2015) 
berjudul "Pengembangan Perangkat. Pembelajaran E-Learning. Mata Kuliah Wawasan. Pendidikan Dasar,. Telaah Kurikulum. Pendidikan Dasar,. Pendidikan Ips. Sekolah Dasar. Perspektif Global. Dan Problematika. Pendidikan Dasar". Wayan Lamawan menunjukkan pendekatan penelitian kombinatif (Mix Method) sangat sesuai untuk memperdalam materi, pengkategorian materi, dan penggunaan materi sehingga memudahkan dalam konten $e$ learning secara maksimal. Persamaan penelitian Wayan dengan penelitian ini yaitu sama-sama menggunakan konten E-Learning. Sedangkan perbedaannya pada penelitian Wayan konten $E$ learning digunakan dalam pengembangan perangkat pembelajaran dan penelitian ini konten E-learning digunakan dalam meningkat strategi pembelajaran.

\section{SIMPULAN}

Rudi (Rumah. Diskusi) sebagai aplikasi yang membantu diskusi antar siswa dan guru ketika di rumah maupun di sekolah, selain itu menjadi alternatif dan memiliki daya tarik untuk para peserta didik dalam belajar maupun berdiskusi. Selain memiliki manfaat akademik tersebut Rudi (Rumah Diskusi) juga memiliki manfaat non akademik berupa meningkatkan kemampuan bersosialisasi siswa dalam bentuk tulisan atau menulis. Sehingga dapat mengungkap keefektifan Rudi. sebagai upaya inovatif $e$ learning terhadap pencapaian hasil belajar siswa.

\section{DAFTAR PUSTAKA}

Aminoto, Tugiyo dan Haerul Pathoni. 2014. "Penerapan Media E-Learning Berbasis Schoology Untuk Meningkatkan Aktivitas dan Hasil Belajar Materi Usaha dan Energi Di Kelas XI SMA N 10 Kota Jambi”. Jurnal Sainmatika. Vol. 8,. No. 1. Hal 13-29.

Candrawati, Sri Rahayu. 2010. "Pemanfaatan ELearning dalam Pembelajaran". Cakrawala Kependidikan. Vol. 8, No. 2. Hal 172-181.

Darmayanti, Tri, Made Yudhi Setiani dan Boedhi Oetojo. 2007. "E-Learning. Pada Pendidikan Jarak Jauh: Konsep Yang Mengubah Metode Pembelajaran Di Perguruan Tinggi Di Indonesia”. Jurnal
Pendidikan Terbuka dan. Jarak Jauh. Vol. 8, No. 2. Hal 99-113.

Goyal, Nitin, Mayank Dave, Anil K Verma. 2019. "Data Aggregation. in Underwater Wireless Sensor Network: Recent Approaches and. Issues". Journal of King Saud University - Computer in Information Sciences. 31. Hal 275-286.

Hafsah, Nandya. R.J, dkk. 2016. "Penerapan. Media Pembelajaran. Modul Elektronik. Untuk Meningkatkan Hasil Belajar Siswa Pada Mata Pelajaran Teknologi Mekanik". Journal of Mechanical Engineering Education. Vol. 3, No. 1. Hal. 106-112.

Hanum, Numiek. Sulistyo. 2013. "Keefektifan ELearning Sebagai Media Pembelajaran (Studi Evaluasi Model Pembelajaran ELearning Smk Telkom Sandhy Putra. Purwokerto)". Jurnal Pendidikan Vokasi. Vol. 3, No. 1. Hal. 90-102.

Hendrastomo, Grendi."2008. "Dilema dan Tantangan Pembelajaran E-Learning". Majalah Ilmiah Pembelajaran. Vol. 4, No.1. Hal 1-13.

Huda, Miftahul. 2018. "Blended Learning: Improvisasi dalam Pembelajaran Menulis Pengalaman". Lensa: Kajian Kebahasaan, Kesusastraan, dan Budaya. Vol. 8, No. 2, Hal 117-130. https://scholar.google.co.id/citations?user= 2khmvhsAAAAJ\&hl=id

Islamiyah, Mufidatul dan Lilis Widayanti. 2016. "Efektifitas Pemanfaatan E-Learning. Berbasis Website Terhadap Hasil Belajar Mahasiswa. STMIK Asia Malang Pada. Mata Kuliah. Fisika Dasar".. Jurnal Ilmiah. Teknologi dan. Informasi ASIA. (JITIKA).Vol, 10.. No, 1. Hal, 41-46..

Jauhari, Jaidan dan Mohammad Bin Ibrahim. 2010. "Intelligent Tutoring System sebagai Upaya Inovatif dalam Pembelajaran untuk Pembelajaran Berbantuan Komputer". JURNAL. GENERIC. Vol. 5, No. 2. Hal 16.

Kusuma, Ade. 2011. "E-Learning. dalam Pembelajaran". LENTERA PENDIDIKAN.. Vol. 14, No. 1. Hal 35-51.

Kosasi, Sandy. 2015. "Perancangan E-Learning untuk Meningkatkan Motivasi Belajar Guru. dan Siwa". Prosiding Seminar 
Nasional Pendidikan Informatika (SENAPATI 2015). Hal. 82-88.

Lasmawan, Wayan. 2015. "Pengembangan Perangkat Pembelajaran E-Learning Mata Kuliah Wawasan Pendidikan Dasar, Telaah Kurikulum Pendidikan Dasar, Pendidikan Ips Sekolah Dasar, Perspektif Global Dan Problematika Pendidikan Dasar". Jurnal Pendidikan. Indonesia. Vol. 4. No, 1. Hal, 566-570.

Listyorini, Tri. 2013. "Perancangan. Mobile Learning. Mata Kuliah. Sistem Operasi. Berbasis Android". SIMETRIS, Vol 3 No 1. Hal, 25-30.

Nasucha, Yakub, dkk. 2015. "Pembelajaran Inovatif Bahasa Indonesia: Implementasi Strategi Pengembangan Paragraf Dan Tanya Jawab Antar Siswa". Warta. Vol. 18. No. 2. Hal 145-152. https://doi.org/10.23917/warta.v18i2.1955

Panji, Wisnu Wirawan. "Pengembangan Kemampuan E-learning Web ke dalam MLearning". Jurnal Masyarakat Informatika. Vol, 2. No, 4.

Purnomo, Agus, Nurul Ratnawati dan Nevy Farista Aristin. 2016. "Pengembangan Pembelajaran Blended Learning Pada Generasi Z". Jurnal Teori dan Praksis Pembelajaran. IPS. Vol. 1, No. 1. Hal 7077.

Ratnasari, Anita. 2012. “ Studi. Pengaruh Penerapan E-Learning terhadap Keaktifan Mahasiswa dalam Kegiatan Belajar Mengajar Studi Kasus Universitas Mercu Buana Jakarta". SNATI.

Susanti, Erma dan Muhammad Sholeh. "Rancang. Bangun Aplikasi E-Learning". Jurnal Teknologi. Vol. 1,. No. 1. Hal 53-57.

Winarno dan Johan Setiawan. 2013. "Penerapan Sistem E-Learning pada Komunitas Pendidikan Sekolah Rumah (Homeschooling)". ULTIMA InfoSys. Vol. 4, No. 1. Hal 45-51.

Yazdi, Mohammad. 2012. "E-Learning Sebagai Media Pembelajaran Interaktif Berbasis Teknologi Informasi". Jurnal Ilmiah Foristek. Vol. 2, No. 1. Hal 143-152.

Zainuri dan Eko Marpanaji. 2012. "Penerapan ELearning Moodle Untuk Pembelajaran Siswa Yang Melaksanakan Prakerin."
Jurnal Pendidikan Vokasi. Vol. 2, No. 3. Hal. 410-426. 